\title{
Biologic Activity of Digoxin-Specific Antisera
}

\author{
John F. Watson and Vincent P. Butler, Jr. \\ From the Departments of Medicine, School of Medicine, State University of \\ New York at Buffalo and the Buffalo General Hospital, Buffalo, \\ New York 14203, and from the Department of Medicine, \\ Columbia University College of Physicians and Surgeons, \\ New York 10032
}

\begin{abstract}
A в S T R A C T Digoxin-specific antibodies are capable of removing essentially all intracellular digoxin from rat renal cortical slices or from human erythrocytes. In removing digoxin from erythrocytes, these antibodies are capable of reversing an effect of the drug on cellular potassium transport. This study provides direct evidence that antibodies are capable of removing, and thereby reversing the biological effect of, physiologically active low molecular weight substances after they have been taken up by mammalian cells. This biologic property of digoxin-specific antibodies suggests that antidigoxin sera may prove useful in the reversal of digoxin toxicity.

Rapid and essentially quantitative removal of digoxin from red cells by antibody is not accompanied by an immediate restoration of potassium influx to normal levels. Identification of the mechanism of this phenomenon may provide useful information concerning the mode of action not only of digoxin, but also of the cation transport system of human erythrocytes.
\end{abstract}

\section{INTRODUCTION}

Antibodies specific for biologically active molecules of high molecular weight, such as tetanus and diphtheria toxins, have long been known to be capable of acting as specific antagonists of their respective antigens (3). Antibodies specific for such antigens have, in general,

This work was presented to the American Federation for Clinical Research at the Eastern Sectional Meeting, 9 December 1967, Philadelphia, $\mathrm{Pa}$. (1) and at the National Meeting, 5 May 1968, Atlantic City, N. J. (2).

Dr. Watson died 14 April 1968. He was the recipient of a Research Career Development Award (AM-13183) from the National Institute of Arthritis and Metabolic Diseases. Dr. Butler is the recipient of a Research Career Development Award (HE-11315) from the National Heart Institute; he was formerly a Senior Investigator of The Arthritis Foundation.

Received for publication 2 August 1971 and in revised form 19 October 1971. not been shown to be capable of reversing the biological actions of these antigens; that such immunological reversal of physiological activity is possible, however, has been clearly demonstrated by the finding that antibodies to thyrotrophin and to insulin are capable of reversing the action of these polypeptide hormones on certain receptor cells in vitro (4).

Antibodies capable of binding pharmacologically active low molecular weight compounds can be elicited in the serum of animals immunized with synthetic hapten-protein conjugates $(5,6)$. In contrast to antibodies to protein antigens, however, little is known about the capacity of such hapten-specific antibodies to act as specific antagonists of the biologically active compounds for which they exhibit immunological specificity. Evidence has been presented that antibodies specific for steroid hormones (7-9), serotonin (10), pyridoxal (11), histamine (12), angiotensin (13), and bradykinin (14) possess the capacity, by virtue of their ability to bind these substances, of inhibiting certain physiological effects of these compounds on various tissues, either in vitro or in vivo. In each instance, however, the binding of hapten by specific antibody could have occurred in extracellular fluids. To our knowledge, the ability of hapten-specific antibodies to remove a specific biologically active compound from cells and to reverse a physiological effect of this substance after it has entered into, or been bound by, these cells has never been directly demonstrated.

The demonstration of the capacity of antibodies specific for a pharmacologically active hapten to remove the corresponding drug from cells would be of considerable general importance because such antibodies might then be useful as specific antagonists of the compound in studies of its mechanism of action and, perhaps of greater immediate value, in the reversal of toxicity resulting from excessive tissue levels of the specific pharmacologic agent. 
It is the purpose of this report to present evidence that antisera specific for the cardiac glycoside, digoxin (15), are capable of binding digoxin in biologic systems and, in so doing, interfere with the pharmacologic effects of the glycoside. Evidence will be presented that antidigoxin sera are capable of removing essentially all of the intracellular glycoside from renal cortical slices of rats or from human erythrocytes and that, in so doing, these antibodies are capable of reversing an effect of digoxin on cellular cation transport. The potential value of these antibodies in the reversal of digoxin toxicity and in the study of the effect of digoxin on cation transport will be discussed.

\section{METHODS}

\section{Albumin-digoxin conjugates}

Synthetic human serum albumin-digoxin (HSA-Dig) ${ }^{1}$ and bovine serum albumin-digoxin (BSA-Dig) conjugates were prepared by the periodate oxidation method $(15,16)$, as described in detail elsewhere (17).

\section{Immunological}

After control preimmunization sera had been obtained, rabbits were immunized by the injection of HSA-Dig or BSA-Dig, $1 \mathrm{mg} / \mathrm{ml}$, in an emulsion containing equal volumes of $0.85 \% \mathrm{NaCl}$ and Freund's complete adjuvant mixture. An initial series of three weekly $0.6-\mathrm{ml}$ injections $(0.1 \mathrm{ml}$ into each of two front-toe pads and $0.2 \mathrm{ml}$ into each two rear-toe pads) was carried out; 0.4-ml booster injections were given intramuscularly at varying intervals thereafter. Antiserum was obtained 5-7 days after completion of the initial series of injections and after subsequent booster injections.

Control sera were obtained from rabbits immunized in a similar manner with human serum albumin (HSA), ${ }^{2}$ bovine serum albumin (BSA), ${ }^{2}$ hen ovalbumin, ${ }^{3}$ human $\gamma$-globulin (HGG), whole human serum, and purin-6-oyl-HSA (PurHSA; [18]) or folic acid-BSA (BSA-FA). ${ }^{5}$ Control sera were also obtained from rabbits which had received no antigen or which had failed to form detectable antibody to cytochrome $\mathrm{C}$ or to human hemoglobin.

Antidigoxin antibodies were raised in sheep by the intramuscular injection of BSA-Dig, $1 \mathrm{mg} / \mathrm{ml}$ in complete Freund's adjuvant mixture, twice monthly for a 4 month period. ${ }^{7}$ Thimerosal $^{8}$ in a final concentration of $1: 10,000$ was added to all rabbit and sheep sera as a preservative.

${ }^{1}$ Abbreviations used in this paper: BSA-Dig, bovine serum albumin-digoxin; BSA-FA, folic acid-BSA; HGG, human $\gamma$-globulin; HSA-Dig, human serum albumin-digoxin; PurHSA, purin-6-oyl-HSA; RBC, red blood cells.

Fraction V powder, Pentex Biochemicals, Kankakee, Ill.

${ }^{3}$ Ovalbumin, 2x crystallized, Mann Research Labs, Inc., New York.

'Fraction II powder, E. R. Squibb \& Sons, New York; supplied through the generosity of the American Red Cross.

${ }^{5}$ Butler, V. P., and J. Lindenbaum. Unpublished experiments.

- Kindly supplied by Dr. Morris Reichlin, Department of Medicine, State University of New York at Buffalo.

${ }^{7}$ Kindly performed by Dr. Donald H. Schmidt, Department of Medicine, Columbia University, New York.

${ }^{8}$ Merthiolate, Eli Lilly \& Co., Indianapolis, Ind.
To determine the quantity of antigen necessary to absorb antibodies to HSA or to HSA-Dig from anti-HSA-Dig sera, quantitative precipitin analyses were performed according to a method outlined by Kabat (19), employing the Folin-Ciocalteu color reaction for analysis of specific precipitates. After determining the quantity of HSA or of HSADig necessary to remove all precipitating antibody at equivalence, an appropriate amount of antigen in a small volume of isotonic $\mathrm{NaCl}$, buffered in some instances with phosphate at $\mathrm{pH} 7.4$, was added to 5 or $10 \mathrm{ml}$ antiserum. After $1 \mathrm{hr}$ at $37^{\circ} \mathrm{C}$, the antiserum was placed at $4^{\circ} \mathrm{C}$ for several days with frequent centrifugation at $2000 \mathrm{rpm}$ until no further precipitation occurred. The absorbed supernatant serum was then decanted and stored at $4^{\circ} \mathrm{C}$ until studied.

Purified $\gamma$-globulin was obtained from each of several individual sera by dialysis against starting buffer and chromatography on a $2.5 \times 30 \mathrm{~cm}$ column of DEAE-cellulose ${ }^{\circ}$ in $0.03 \mathrm{M}$ phosphate buffer, $\mathrm{pH} 7.0$, or DEAE-Sephadex A-25 ${ }^{10}$ in $0.01 \mathrm{M}$ phosphate buffer, $\mathrm{pH} 7.0 ; \gamma$-globulin was obtained as the first $280 \mathrm{~m} \mu$-absorbing peak to appear from such a column (20). Purified $\gamma$-globulin was also prepared in a similar manner from pooled normal rabbit Fraction II ${ }^{11}$ by

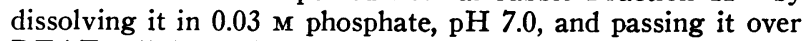
DEAE-cellulose. After concentration by negative pressure dialysis, each purified protein fraction was dialyzed against $\mathrm{pH} 7.45$ Tris-buffered saline (21). Four of six preparations contained only proteins which migrated as $\boldsymbol{\gamma}$-globulins on filter paper electrophoresis; the fractions from two antiHSA-Dig sera (DB-38, DB-45) contained small amounts of $\beta$-globulin.

Equilibrium dialysis experiments were carried out at $4^{\circ} \mathrm{C}$ in isotonic Tris-buffered saline, $\mathrm{pH} 7.45$ (21). $2 \mathrm{ml}$ of $\gamma$ globulin or $9 \mathrm{ml}$ of test serum, diluted in this buffer, was placed inside Visking dialysis tubing ${ }^{12}$ and dialyzed in a test tube against an equal volume of buffer in the presence of randomly labeled digoxin- ${ }^{3} \mathrm{H}$ (Dig- ${ }^{3} \mathrm{H}$ ) ${ }^{18}$ added in a concentration of $0.016-0.027 \mu \mathrm{g} / \mathrm{ml}$ either inside or outside the membrane. After 5 days of mechanical mixing, $0.5-\mathrm{ml}$ portions from inside and outside the dialysis membrane were added to $15 \mathrm{ml}$ of a modified Bray's scintillation mixture (23) ; the latter solution contained $242 \mathrm{mg} \mathrm{1,4-bis-2-(4-}$ methyl-5-phenyloxazolyl)-benzene, ${ }^{14} 4 \mathrm{~g}$ 2,5-diphenyloxazole, ${ }^{14}$ $60 \mathrm{~g}$ naphthalene, $20 \mathrm{ml}$ ethylene glycol, and $100 \mathrm{ml}$ methanol made up to 1 liter with dioxane. Measurements of radioactivity were carried out in a Tri-Carb liquid scintillation counter ${ }^{14}$ equipped with automatic external standardization. The mean recovery of added radioactivity was $94 \%$ ( $\pm \mathrm{SD}$

\footnotetext{
${ }^{\circ}$ Schleicher \& Schuell Inc., Keene, N. H.

${ }^{10}$ Pharmacia Fine Chemicals, Inc., Piscataway, N. J.

${ }^{11}$ Pentex Biochemicals, Kankakee, IIl.

${ }^{12}$ Union Carbide Corp., Food Products Div., Chicago, Ill.

${ }^{13}$ Lots $\mathrm{G} 448(112.6 \mu \mathrm{Ci} / \mathrm{mg})$, L499 $(126 \mu \mathrm{Ci} / \mathrm{mg})$, and $\mathrm{R} 907(144 \mu \mathrm{Ci} / \mathrm{mg})$, generously supplied by Dr. Stanley $\mathrm{T}$. Bloomfield, Burroughs Wellcome \& Co., Research Triangle Park, N. C. All three lots contained less than 2\% radiochemical impurities as determined by paper chromatography using a formamide-saturated paper strip and chloroform saturated with formamide as the mobile phase (courtesy of $\mathrm{Mr}$. James E. Murphy, Analytical Research Department, Burroughs Wellcome \& Co., Inc.). After the completion of the experiments described herein, lot L499 was also shown to be radiochemically pure by thin-layer chromatography (22), but lot R907 (used only in the experiment shown in Table V) was found to contain between 10 and $20 \%$ radioactive impurities, when analyzed by this method.
}

${ }^{14}$ Packard Instrument Co., Inc., Downers Grove, Ill. 
$7 \%$ ); no significant bag binding (24) nor quenching was observed with the dilutions of serum or $\gamma$-globulin used in these experiments. The concentration of protein-bound radioactivity was determined by subtracting the concentration of free radioactivity (as measured outside the dialysis bag) from the total concentration of radioactivity inside the bag. The percentage of digoxin bound by antibody was then expressed as the percentage of total recovered radioactivity found to be protein bound.

\section{Tissue uptake of digoxin}

Rat renal cortical slices. Holtzman rats weighing approximately $200 \mathrm{~g}$ were sacrificed and the kidneys rapidly removed and placed in ice-cold buffer, containing $\mathrm{NaCl} 115$ $\mathrm{mm}, \mathrm{KCl} 5 \mathrm{~mm}, \mathrm{MgSO}_{4} 1.2 \mathrm{~mm}, \mathrm{CaCl}_{2} 1.0 \mathrm{~mm}, \mathrm{Na}$ acetate $10 \mathrm{~mm}$, and Tris $25 \mathrm{~mm}$, adjusted to $\mathrm{pH} 7.4$ with $\mathrm{HCl}$. Thin slices of cortex weighing approximately $100 \mathrm{mg}$ were cut with a Stadie-Riggs microtome ${ }^{15}$ and placed in $25-\mathrm{ml}$ Erlenmeyer flasks containing $1 \mathrm{ml}$ of buffer. The flasks were preincubated at $25^{\circ} \mathrm{C}$ in a Dubnoff metabolic shaking incubator ${ }^{16}$ for $30-60 \mathrm{~min}$. After the preincubation period, $1 \mathrm{ml}$ of buffer containing Dig- ${ }^{3} \mathrm{H}$ and inulin- ${ }^{14} \mathrm{C}$ (footnotes 13 and 17) was added to each flask together with carrier digoxin to obtain the desired medium concentration of the glycoside. The slices were incubated at $25^{\circ} \mathrm{C}$ for specified intervals. At the specified times, duplicate flasks were removed from the shaker and a portion of medium quickly withdrawn from each for isotopic counting. The remainder of the medium was rapidly separated from the slice by pouring the contents of each flask onto filter paper in a Gooch crucible placed in a filtering flask attached to a vacuum pump. The slices on the filter paper were washed three times with cold $0.85 \% \mathrm{NaCl}$, blotted on filter paper and placed on a torsion balance for determination of wet weight. Since evaporation loss was small and constant, no correction was made. The slices were then digested in $2 \mathrm{ml}$ of boiling water for $5 \mathrm{~min}$, and a portion of the supernatant was removed for counting. For determination of dry weight, additional sets of duplicate slices handled in a similar manner, except for the water digestion, were dried at $100^{\circ} \mathrm{C}$ in a vacuum oven for $8-12 \mathrm{hr}$, or until constant dry weight was obtained.

In order to study the effect of various test sera on the digoxin distribution ratios, the slices were allowed to incubate with the desired medium concentration of digoxin for $60 \mathrm{~min}$ in order to reach a steady state (see Fig. 1). Then 0.5 to $1.0 \mathrm{ml}$ of test serum or $\gamma$-globulin solution was added to the flasks and incubation continued for an additional time period, after which the slices and medium were handled as described above.

In all rat kidney slice experiments, counting was performed in a Mark I Model No. 6860 Nuclear Chicago liquid scintillation counter ${ }^{18}$ with Bray's solution (23) as the scintillation mixture. The external standard procedure for doubly labeled samples was used as described in the operating manual for the counter. Counting error was less than $1 \%$. Commercially prepared water-quenched ${ }^{14} \mathrm{C}$ and ${ }^{8} \mathrm{H}$ standards in Bray's solution were used to prepare the quench correction curves. Using these methods of extraction and counting, the recovery of the isotopes was greater than $95 \%$.

${ }^{15}$ Arthur H. Thomas Co., Philadelphia, Pa.

${ }^{16}$ Precision Scientific Company, Chicago, Ill.

${ }^{17}$ Inulin-carboxyl-14 $\mathrm{C}, 1-3 \mathrm{mCi} / \mathrm{g}$ was obtained from the New England Nuclear Corp., Boston, Mass.

${ }^{18}$ Nuclear-Chicago, Des Plaines, Ill.
Intracellular water was calculated as the difference between wet and dry tissue weights, less the volume of the extracellular (inulin- ${ }^{14} \mathrm{C}$ ) space (25). After correcting for extracellular $\mathrm{Dig}-{ }^{3} \mathrm{H}$ in the inulin- ${ }^{14} \mathrm{C}$ space, the intracellular (actually, intracellular and/or cell membrane bound) $\mathrm{Dig}^{-}{ }^{3} \mathrm{H}$ concentration in the tissue slice was determined. The distribution ratio of digoxin was then calculated by the method of Rosenberg, Blair, and Segal (26) as the ratio of digoxin concentration (Dig- ${ }^{3} \mathrm{H} \mathrm{dpm} / \mathrm{ml}$ ) in intracellular fluid to its concentration in extracellular fluid (equivalent to $\mathrm{Dig}^{3} \mathrm{H}$ $\mathrm{dpm} / \mathrm{ml}$ in the supernatant medium).

Extent of kidney slice metabolism and degradation of $D i g-{ }^{s} \mathrm{H}$. Slices were prepared, incubated, washed, and digested as described above. A $0.5 \mathrm{ml}$ aliquot of the water digest was extracted with $20 \mathrm{ml}$ chloroform and the extract passed through a $100-200$ mesh activated alumina ${ }^{10}$ column $(5 \times 0.5 \mathrm{~cm})$. The column was eluted with a $2: 1$ chloroform-ethanol mixture into a counting vial and evaporated to dryness (27). The resultant residue was dissolved in $0.5 \mathrm{ml}$ $95 \%$ ethanol, scintillation mixture was added, and the vial was counted as described above. In four tissue extracts, $100 \%$ of the tritium counts were recovered from the column, indicating that no significant amount of labeled metabolite or degradation product had been adsorbed to the column. Approximately $98 \%$ of the radioactivity was recovered in the first $10 \mathrm{ml}$ of the chloroform-ethanol eluate.

Samples of the eluates from additional tissue extracts were dried, redissolved in 95\% ethanol, and applied to thin-layer chromatography plates of Silica Gel G; pure digoxin and digoxigenin controls were also applied. After ascending chromatography in a solvent system of cyclohexane : acetone: glacial acetic acid in a ratio of $49: 49: 2$ (22), the fractions were identified by spraying with chloramine $\mathrm{T}$-trichloroacetic acid solution (28). The developed areas on the chromatography plate (including origin and solvent front) were quantitatively removed and counted for radioactivity. $95 \%$ of all the radioactivity present in the tissue extract eluate was in a fraction which migrated with an $R_{F}$ comparable to that of a digoxin standard. No fraction was visible with an $\mathbf{R}_{\mathbf{F}}$ similar to that of digoxigenin. There was uniformly a faint spot in the water extract eluates which traveled slightly faster than digoxigenin, but it contained no radioactivity and was not further characterized. It was concluded that, during the course of these experiments, no significant metabolism or degradation of labeled digoxin occurred in the renal cortical slices.

\section{Human red blood cell uptake of digoxin}

The red blood cells ( $R B C$ ) from fresh heparinized normal human venous blood were washed twice in $0.85 \% \mathrm{NaCl}$ and suspended overnight in a storage medium containing $\mathrm{NaCl}$ $130 \mathrm{~mm}, \mathrm{NaH}_{2} \mathrm{PO}, 5 \mathrm{~mm}, \mathrm{KCl} 5 \mathrm{~mm}, \mathrm{MgCl}_{2} 1 \mathrm{~mm}$, and glucose $15 \mathrm{~mm}$, adjusted to $\mathrm{pH} 7.4$ with $0.9 \mathrm{~N} \mathrm{NaOH}$. On the day of the study the cells were separated from the storage medium and suspended, at an approximate hematocrit of $16 \%$, in a buffer containing $\mathrm{NaCl} 153 \mathrm{~mm}, \mathrm{KCl} 5 \mathrm{~mm}$, $\mathrm{NaH}_{2} \mathrm{PO}, 2 \mathrm{~mm}$, inosine $10 \mathrm{~mm}$, adenine ${ }^{20} 0.5 \mathrm{~mm}$, and glycylglycine ${ }^{20} 20 \mathrm{~mm}$, adjusted to $\mathrm{pH} 7.4$ with $0.9 \mathrm{~N} \mathrm{NaOH}$ (if obtained on the day of a study, the RBC were washed three times with this latter buffer, before preparation of the final $16 \%$ RBC suspension). 3-ml samples of the RBC suspension in $25 \mathrm{ml}$ Erlenmeyer flasks were preincubated for

\footnotetext{
10 Bio-Rad Laboratories, Richmond, Calif.

${ }^{20}$ Cyclo Chemical, Div. of Travenol Laboratories, Inc., Los Angeles, Calif.
} 
$30 \mathrm{~min}$ at $37^{\circ} \mathrm{C}$ in a Dubnoff metabolic shaking incubator, ${ }^{16}$ through which a continual flow of oxygen was maintained. To each flask was then added $1 \mathrm{ml}$ of a solution containing Dig ${ }^{-3} \mathrm{H}(0.6 \mu \mathrm{Ci} / \mathrm{ml}),{ }^{13}$ carrier digoxin, and inulin- $-{ }^{14} \mathrm{C}(0.36$ $\mu \mathrm{Ci} / \mathrm{ml}) ;{ }^{17} 2 \mathrm{ml}$ of buffer was added at this time to adjust the final volume to $6 \mathrm{ml}$. All determinations were carried out in duplicate. Incubation was continued for an additional $60 \mathrm{~min}$, at which time the contents of the flasks were transferred to plastic centrifuge tubes and spun for $5 \mathrm{~min}$ at $4^{\circ} \mathrm{C}$ and $20,000 \mathrm{~g}$ in a Sorvall RC2B centrifuge. ${ }^{21}$ The supernatant was removed by suction through a Pasteur pipette and three $1 \mathrm{ml}$ samples of the supernatant medium (referred to as "extracellular") were removed for counting. The packed RBC were then hemolyzed by the addition of water to a $3 \mathrm{ml}$ calibration mark on the centrifuge tube. Hemoglobin was precipitated by the addition of $2 \mathrm{ml} 10 \%$ trichloroacetic acid; finally, $1 \mathrm{ml}$ of ethanol or of digoxin, $3 \mathrm{mg} /$ $\mathrm{ml}$ in ethanol, was added (this latter addition was necessary

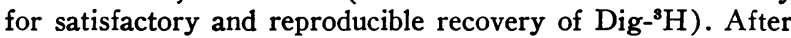
mixing, the centrifuge tubes were again spun 5 min under the above conditions and three $1 \mathrm{ml}$ samples of the supernatant (referred to as "cellular") were removed for counting.

In experiments designed to study the effect of test sera on the digoxin uptake of $\mathrm{RBC}$, the cells were allowed to incubate with digoxin for $60 \mathrm{~min}$ in a $4 \mathrm{ml}$ volume. At that time, $2 \mathrm{ml}$ of buffer or test serum was added to each of two duplicate flasks (all sera had been heated at $56^{\circ} \mathrm{C}$ for 30 min to inactivate complement, and absorbed three times with washed human $\mathrm{RBC}$ to remove heterophile anti-RBC antibodies). Incubation was continued for various intervals thereafter; the contents were then transferred to plastic centrifuge tubes and handled as described above.

In early experiments, radioactivity was determined by methods identical with those employed in the kidney slice experiments. However, more recently available batches of inulin $-{ }^{14} \mathrm{C}$ have been extremely unstable in the usual liquid scintillation counting solutions. Satisfactory accuracy and reproducibility could be obtained by the addition of the three $1 \mathrm{ml}$ portions of the above extracellular and cellular supernatants to $15 \mathrm{ml}$ of liquid scintillation mixture contain-

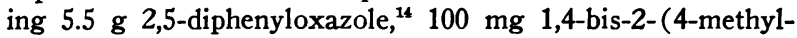
5-phenyloxazolyl)-benzene, ${ }^{14}$ and $333 \mathrm{ml}$ Triton X-100 ${ }^{14}$ made up to 1 liter with toluene (29). To one portion of each supernatant specimen was then added an internal standard solution containing $0.15-0.18 \mu \mathrm{Ci} \mathrm{Dig-}{ }^{8} \mathrm{H}$ and to another portion was added an internal standard solution containing 0.06 $\mu \mathrm{Ci}$ inulin- ${ }^{14} \mathrm{C}$. The vials were shaken vigorously, placed for $1 \mathrm{hr}$ at $4^{\circ} \mathrm{C}$ in the absence of light, shaken again, and counted immediately in a Tri-Carb liquid scintillation counter. ${ }^{14}$ Using internal standard increments to calculate efficiencies, ${ }^{14} \mathrm{C}$ and ${ }^{3} \mathrm{H}$ dpm in the extracellular and cellular fluids were determined. The volume of the extracellular (inulin- ${ }^{11} \mathrm{C}$ ) space in the cellular specimen was calculated on the basis of the inulin ${ }^{14} \mathrm{C}$ concentration observed in the extracellular supernatant fluid. Then, by correcting for extracellular $\mathrm{Dig}-{ }^{8} \mathrm{H}$ in this inulin- ${ }^{14} \mathrm{C}$ space, the total cellular Dig- ${ }^{8} \mathrm{H}$ in the packed $\mathrm{RBC}$ was calculated. The $\mathrm{RBC}$ volume was calculated by assuming that $100 \mathrm{ml}$ RBC contain $34 \mathrm{~g}$ hemoglobin (30), as determined by the cyanmethemoglobin method, using Drabkin's solution (31). Using this volume of $R B C$ and the specific activity of Dig- ${ }^{3} \mathrm{H}$ (in $\mathrm{dpm} / \mu$ mole digoxin), the RBC uptake of digoxin was calculated and expressed as $\mu$ moles/liter RBC.

${ }^{21}$ Ivan Sorvall Inc., Norwalk, Conn.

\section{Potassium influx in human RBC (30)}

$\mathrm{RBC}$ suspensions were prepared in the glyclyglycine buffer described above. $3-\mathrm{ml}$ portions of the $16 \% \mathrm{RBC}$ suspension were preincubated for $30 \mathrm{~min}$ at $37^{\circ} \mathrm{C}$ in the same shaking incubator, with continual oxygen flow, as described above. To each flask was then added $1 \mathrm{ml}$ of $6 \times 10^{-5} \mathrm{M}$ digoxin or $1 \mathrm{ml}$ of digoxin-free buffer. At that time or at various intervals thereafter, $2 \mathrm{ml}$ buffer, control serum, or antidigoxin serum was added to each of two duplicate flasks; all sera had previously been heated $30 \mathrm{~min}$ at $56^{\circ} \mathrm{C}$ and absorbed three times with washed human RBC. $1 \mathrm{hr}$ after the addition of buffer or serum, $200 \mu \mathrm{l}{ }^{42} \mathrm{KCl}(1 \mu \mathrm{Ci} / \mathrm{ml})^{22}$ was added to each flask, and incubation was continued for an additional $60 \mathrm{~min}$. At this time, the contents of each flask were transferred to centrifuge tubes and spun at $4^{\circ} \mathrm{C}$ at $20,000 \mathrm{~g}$ for $5 \mathrm{~min} .4 \mathrm{ml}$ of the supernatant was removed for counting, and the remainder saved for $\mathrm{K}^{+}$determination. The packed cells were washed three times at $4^{\circ} \mathrm{C}$ with $6-\mathrm{ml}$ portions of 280 mosomolar $\mathrm{MgCl}_{2}$ (30). The washed cells were hemolyzed in $5 \mathrm{ml} \mathrm{H}_{2} \mathrm{O}$ and the hemolysate counted in a Packard Auto-Gamma Counter. ${ }^{14}$ RBC volume was again calculated as outlined in the preceding section, and the supernatant solutions were stored at $-20^{\circ} \mathrm{C}$ for several days to allow for the radioactive decay of ${ }^{42} \mathrm{~K} \quad\left(t_{1}=12.4\right.$ $\mathrm{hr}$ ). The potassium concentration of the supernatant solution was then determined with a flame photometer ; ${ }^{23}$ using the observed potassium concentration to calculate the specific activity of ${ }^{2} \mathrm{~K}$ in the supernatant medium (cpm per millimole $\mathrm{K}^{+}$), potassium influx was expressed as millimoles of $\mathrm{K}^{+}$per liter of red cells per hour $(30)$.

\section{RESULTS}

Equilibrium dialysis experiments. In Tables I-III are listed the percentages of $\mathrm{Dig}^{-}{ }^{\mathrm{B}} \mathrm{H}$ bound in equilibrium dialysis experiments when a constant amount of Dig- ${ }^{3} \mathrm{H}$ was added to various dilutions of the sera and $\gamma$-globulin preparations employed in this study. It is clear that antidigoxin sera possess a potent digoxin-binding capacity (Table I) and that this capacity is a property of the $\gamma$-globulin fractions of these sera (Table II). The digoxin-binding capacity was not present in preimmunization sera (Table I) nor in $\gamma$-globulin fractions derived therefrom (Table II). The acquired ability to bind digoxin was not a nonspecific result of immunization because antisera to HSA and other antigens lacked this capacity (Table III). Furthermore, removal of antibodies to HSA from anti-HSA-Dig sera did not affect their digoxin-binding capacity whereas absorption of antibodies to HSA and digoxin with an HSA-Dig conjugate did diminish the digoxin-binding capacity significantly (Table IV). Evidence that this binding is specific for digoxin has been presented previously $(15,17)$.

Extracellular space and dry weight determination of the kidney slices. The extracellular space of the kidney

${ }^{22}$ Iso/Serve Division, Cambridge Nuclear Corp., Cambridge, Mass.

${ }_{23}$ Model 143, Instrumentation Laboratory, Inc., Watertown, Mass.

Biologic Activity of Digoxin-Specific Antisera 
TABLE I

Ability of Rabbit Serum Obtained before, and after, Immunization with HSA-Dig to Bind Digoxin and to Remove Digoxin from Rat Renal Cortical Slices

\begin{tabular}{clcc}
\hline Rabbit & Nature of serum & $\begin{array}{c}\text { \% digoxin } \\
\text { bound in } \\
\text { equilibrium } \\
\text { dialysis } \\
(1: 20 \text { serum } \\
\text { dilution })\end{array}$ & $\begin{array}{c}\text { Distribu- } \\
\text { tion ratio* } \\
\text { of digoxin } \\
\text { in renal } \\
\text { slice } \\
\left(10^{-5} \mathrm{M}\right. \\
\text { digoxin })\end{array}$ \\
\hline DB- & Preimmunization & 3.8 & 1.28 \\
DB-44 & Preimmunization & 3.8 & 1.19 \\
DB-46 & Preimmunization & 4.9 & 1.25 \\
DB-34 & Anti-HSA-Dig & 97.7 & 0.00 \\
DB-44 & Anti-HSA-Dig & 97.1 & 0.04 \\
DB-46 & Anti-HSA-Dig & $98.2 \ddagger$ & 0.02 \\
\hline
\end{tabular}

* Ratio of intracellular to extracellular Dig- ${ }^{3} \mathrm{H}$ concentration after $1 \mathrm{hr}$ of incubation with digoxin followed by a subsequent $1 \mathrm{hr}$ exposure to serum $(0.5 \mathrm{ml})$.

$\ddagger 1: 100$ serum dilution employed.

slice as determined by the inulin $-{ }^{14} \mathrm{C}$ space averaged $25 \%$ ( $\mathrm{SD} \pm 3 \%$ ) of the wet tissue weight. These results are in agreement with those reported by others (32). The mean dry weight was $21 \%$ of the wet weight and did not appear to be appreciably affected by changes in the experimental conditions employed in this study.

Slice uptake of digoxin and effect of sera. Fig. 1 shows the time course of uptake of digoxin by renal cortical slices at a medium concentration of $10^{-5} \mathrm{M}$ digoxin. At this concentration, digoxin rapidly accumu-

TABLE II

Ability of $\gamma$-Globulin Fractions of Rabbit Serum to Bind Digoxin and to Remove Digoxin from Rat Renal Cortical Slices

\begin{tabular}{lcc}
\hline & $\begin{array}{c}\text { \% digoxin } \\
\text { bound in } \\
\text { equilibrium } \\
\text { dialysis }\end{array}$ & $\begin{array}{c}\text { Distribution } \\
\text { ratio* in } \\
\text { Source of } \gamma \text {-globulin }\end{array}$ \\
$\begin{array}{c}(30 \mu \mathrm{g} \\
\text { r-globulin }\end{array}$ & $\begin{array}{c}\left(1^{-6} \mathrm{M}\right. \\
\text { digoxin }) \ddagger\end{array}$ \\
\hline Buffer Control & $\mathrm{N} / \mathrm{ml})$ & 2.45 \\
Rabbit DB-36 preimmunization serum & 0.2 & 2.27 \\
Rabbit DB-38 preimmunization serum & 0.0 & 3.15 \\
Rabbit DB-45 preimmunization serum & 0.0 & 3.07 \\
Pooled normal rabbit $\gamma$-globulin & 2.3 & 2.58 \\
Rabbit DB-36 anti-HSA-Dig serum & 0.0 & 0.05 \\
Rabbit DB-38 anti-HSA-Dig serum & 98.3 & 0.50 \\
Rabbit DB-45 anti-HSA-Dig serum & 98.8 & 0.00 \\
\hline
\end{tabular}

* Ratio of intracellular to extracellular Dig-s $\mathrm{H}$ concentration after $1 \mathrm{hr}$ of incubation with digoxin followed by a subsequent $1 \mathrm{hr}$ incubation with $\gamma$-globulin $(0.5 \mathrm{ml}$ of a solution containing $150 \mu \mathrm{g} \mathrm{N} / \mathrm{ml})$.

$\ddagger$ Distribution ratios were higher in control renal slices in this experiment than in that illustrated in Table I because a lower digoxin concentration was employed.
TABLE III

Digoxin Binding by Antisera to Various Antigens as Determined by Equilibrium Dialysis and by their Ability to Remove Digoxin from Rat Renal Cortical Slices

\begin{tabular}{llcc}
\hline Rabbit & Nature of serum & $\begin{array}{c}\text { \% Dig-3 } \\
\text { bound in } \\
\text { equilibrium } \\
\text { dialysis } \\
(1: 20 \text { serum } \\
\text { dilution })\end{array}$ & $\begin{array}{c}\text { Distribution } \\
\text { ratio* in } \\
\text { renal slice } \\
\left(10^{-5} \mathrm{M}\right. \\
\text { digoxin) }\end{array}$ \\
\hline None & Buffer control & 1.3 & 1.83 \\
BSA-3 & Anti-BSA & 3.2 & 1.37 \\
HSA-1 & Anti-HSA & 0.6 & 1.57 \\
HSA-3 & Anti-HSA & 3.5 & 1.52 \\
OVA-1 & Anti-ovalbumin & 0.1 & 1.20 \\
OVA-2, 3 Pool & Anti-ovalbumin & 5.4 & 1.45 \\
WHS-5 & Anti-whole human serum & 3.1 & 1.34 \\
E22-42 & Anti-Pur-HSA & 1.4 & 1.24 \\
FA-10 & Anti-BSA-FA & 0.0 & 1.14 \\
HGG-4 & Anti-HGG & 0.0 & 1.47 \\
\hline
\end{tabular}

* See Table I for definition.

lated in the slices and reached a steady-state distribution ratio of 1.8 by $60 \mathrm{~min}$. Since a distribution ratio of greater than one indicates that the concentration of digoxin in intracellular fluid exceeds its concentration in extracellular fluid, Fig. 1 indicates that the kidney slices are capable of accumulating the glycoside against a concentration gradient.

This accumulation of digoxin provided a system in which the ability of antisera to remove the glycoside from the slice could be studied. Accordingly, after 60 min preincubation with $\mathrm{Dig}^{3} \mathrm{H}$ at a medium concentration of $10^{-6} \mathrm{M}$ digoxin, $0.5 \mathrm{ml}$ of serum was added to

TABLE IV

Effect of Absorption of Anti-HSA-Dig Serum with HSA or with HSA-Dig

\begin{tabular}{|c|c|c|c|}
\hline $\begin{array}{c}\text { Rabbit } \\
\text { No. }\end{array}$ & Absorbing antigen & $\begin{array}{l}\% \text { Dig-8 } \\
\text { bound in } \\
\text { equilibrium } \\
\text { dialysis } \\
\text { (1: } 500 \text { serum } \\
\text { dilution) }\end{array}$ & $\begin{array}{l}\text { Distribution } \\
\text { ratio* in } \\
\text { renal slice } \\
\left(10^{-5} \mathbf{M}\right. \\
\text { digoxin) }\end{array}$ \\
\hline None & Buffer control & 1.4 & 1.83 \\
\hline DB-36 & None & 99.9 & 0.10 \\
\hline DB-38 & None & 98.7 & 0.01 \\
\hline DB-45 & None & 99.9 & 0.07 \\
\hline DB-36 & HSA & ND & 0.00 \\
\hline DB-38 & HSA & 98.1 & 0.02 \\
\hline DB-45 & HSA & 99.3 & 0.12 \\
\hline DB-36 & HSA-Dig & 13.5 & 1.07 \\
\hline DB-38 & HSA-Dig & 7.7 & 1.06 \\
\hline DB-45 & HSA-Dig & 17.6 & 1.31 \\
\hline
\end{tabular}

ND, not done.

* See Table I for definition. 


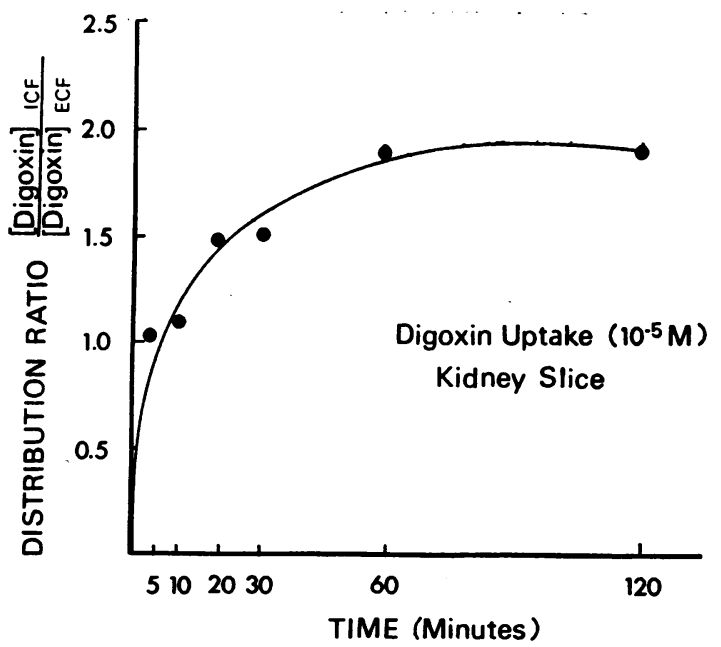

FIGURE 1 Uptake of $10^{-5}$ M digoxin by rat renal cortical slices is plotted as a function of time, in minutes. The distribution ratio is the ratio of the intracellular digoxin concentration to the concentration of digoxin in extracellular fluid.

the medium. Fig. 2 demonstrates the rapidity with which digoxin was removed from slices in the presence of anti-HSA-Dig serum as compared to control serum. The change in distribution ratio is plotted as a function of time. The upper curve demonstrates a slight fall in the distribution ratio after the addition of control nonimmune serum while the lower curve shows the rapid removal of digoxin from the slice by the immune serum. $50 \%$ of the glycoside was removed within $5 \mathrm{~min}$.

In Tables I-III are shown the distribution ratios after $60 \mathrm{~min}$ of incubation with various sera and $\gamma$-globulin preparations. Preimmunization sera(Table I), preimmunization $\boldsymbol{\gamma}$-globulin (Table II), and antisera to a variety of unrelated antigens (Table III) diminished the digoxin concentration in the slice slightly when compared with buffer controls. In contrast, anti-HSADig sera, or $\boldsymbol{\gamma}$-globulin fractions derived from antiHSA-Dig sera, removed almost all of the tissue glycoside as shown by the fall in distribution ratio to less than 0.10 in most instances (Tables I, II, IV). Absorption of antibodies to HSA did not obliterate the effect whereas removal of digoxin antibodies by absorption with the HSA-Dig conjugate did diminish the ability of the sera to remove digoxin from the slices (Table IV).

$R B C$ uptake of digoxin and effect of sera. In Fig. 3, the uptake of digoxin in human $\mathrm{RBC}$ expressed in $\mu$ moles/liter of RBC is plotted as a function of time, in minutes, during $\mathrm{RBC}$ incubation with $10^{-5} \mathrm{M}$ digoxin. It can be seen that, at $60 \mathrm{~min}$, the uptake is $5.44 \mu \mathrm{moles} /$ liter in the presence of buffer alone. Assuming a cell water content of $80 \%$ this value represents a distribution

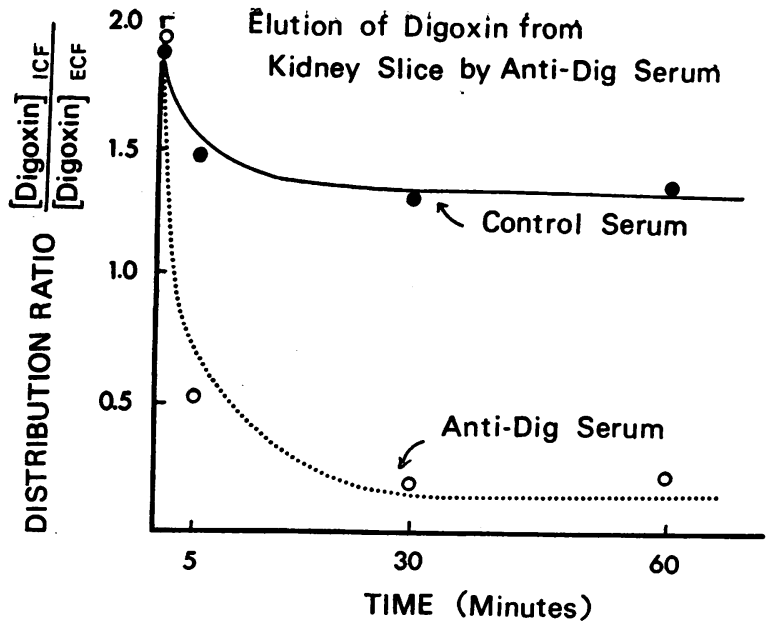

FIGURE 2 Removal of digoxin from rat renal cortical slices by rabbit antidigoxin serum $(O)$, as compared with control rabbit serum $(\bullet)$. Slices had been allowed to incubate $1 \mathrm{hr}$ with $2 \mathrm{ml} 10^{-5} \mathrm{M}$ digoxin to achieve steady-state distribution ratio before adding $0.5 \mathrm{ml}$ serum at 0 min. Distribution ratio (ratio of intracellular to extracellular digoxin concentration) is plotted as a function of time.

ratio of approximately 0.68 ; this uptake of digoxin by human $\mathrm{RBC}$ is in contrast to the uptake against a concentration gradient observed with rat kidney slices (Fig. 1).

To determine whether digoxin-specific antibodies were capable of removing digoxin from human $\mathrm{RBC}$, antidigoxin sera and various control sera were added to human $\mathrm{RBC}$ which had previously been incubated with $1.5 \times 10^{-5} \mathrm{M}$ digoxin for $1 \mathrm{hr}$. Fig. 4 shows the

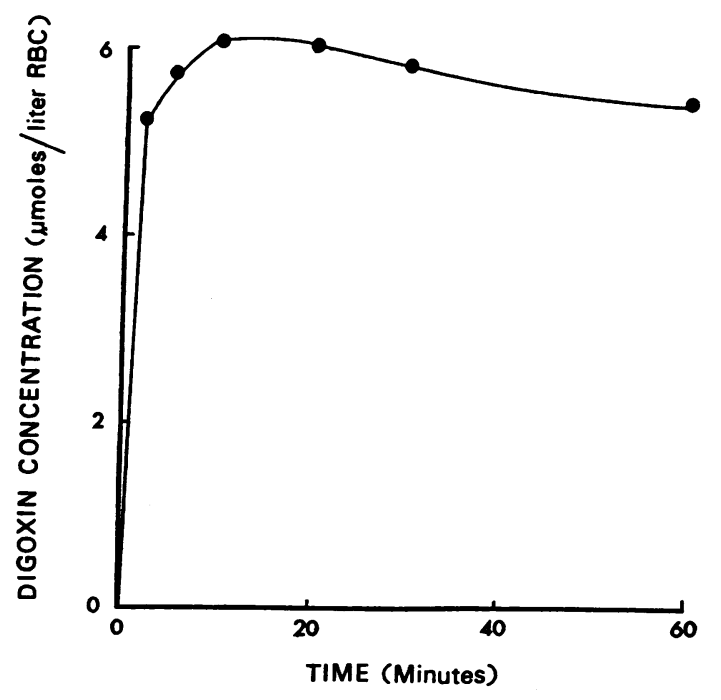

FIGURE 3 Uptake of $10^{-5} \mathrm{M}$ digoxin by human erythrocytes is plotted as a function of time in minutes.

Biologic Activity of Digoxin-Specific Antisera 


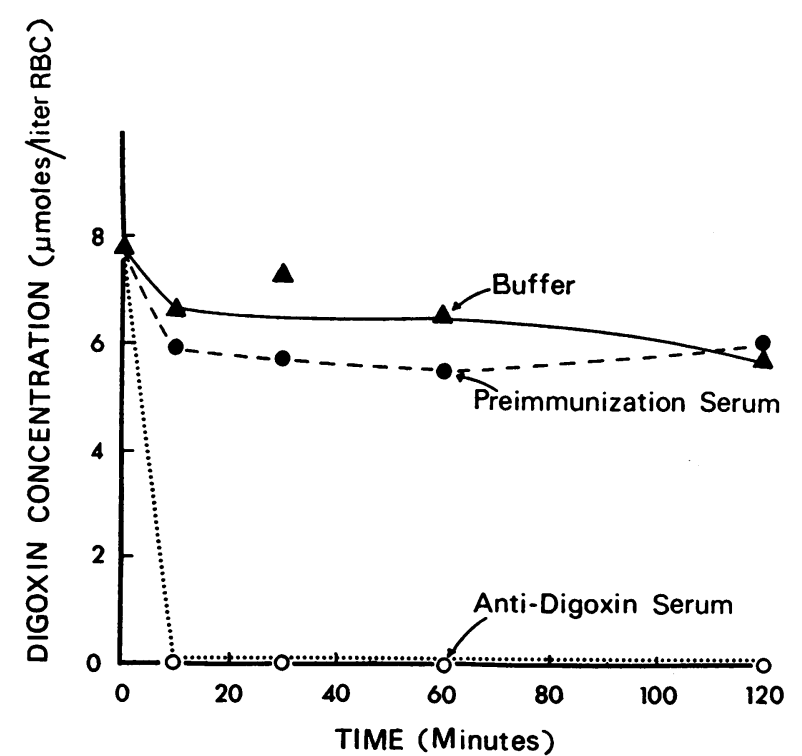

FIgURE 4 Removal of digoxin from RBC by antidigoxin serum. RBC digoxin concentration at various times after the addition, at 0 time of $2 \mathrm{ml}$ of buffer ( $\Delta)$, control serum obtained from sheep S-62 before immunization $(\bullet)$, and antidigoxin serum from sheep S-62 (O) to $4 \mathrm{ml}$ of an $\mathrm{RBC}$ suspension which had been preincubated with $1.5 \times 10^{-5}$ M digoxin for $1 \mathrm{hr}$; final digoxin concentration was $10^{-5} \mathrm{M}$.

rate of removal of digoxin from $\mathrm{RBC}$ in the presence of antidigoxin serum from sheep S-62. Within $10 \mathrm{~min}$, all detectable glycoside had been removed from the cells whereas, in the presence of control serum obtained from the same animal before immunization, removal of digoxin from $\mathrm{RBC}$ was minimal. In Table $\mathrm{V}$, the capacity of various test sera to remove digoxin from human $\mathrm{RBC}$ is illustrated. Only antidigoxin sera were capable of binding the glycoside and of removing it from $\mathrm{RBC}$, as determined by a fall in $\mathrm{RBC}$ digoxin concentration to nondetectable levels (Table V).

Effect of antidigoxin sera on digoxin-induced inhibition of $K^{+}$influx in $R B C$. A known pharmacologic action of the cardiac glycosides is their ability to inhibit cation transport across cell membranes (33). As shown in Table VI, digoxin is capable of inhibition of the influx of potassium into human erythrocytes. In the experiment illustrated in Table VI, $\mathrm{K}^{+}$influx in buffer without digoxin was 1.87 mmoles/liter $\mathrm{RBC}$ per hr. In the presence of test serum without digoxin, there was no significant difference. Digoxin, however, markedly inhibited $\mathrm{K}^{+}$influx, and this inhibition was not affected when control serum was added concomitantly. In the presence of antidigoxin sera, the action of digoxin on potassium transport was inhibited, as shown by the proximity of the $\mathrm{K}^{+}$influx values to the control range.

The results shown in Table VI demonstrate that antidigoxin sera are capable of preventing a known pharmacologic effect of the glycoside when antiserum and digoxin together are added to an RBC suspension. To determine whether or not antisera were capable of reversing the effect of digoxin on $\mathrm{K}^{+}$influx after digoxin had been taken up by the $\mathrm{RBC}$, antidigoxin sera were added to $\mathrm{RBC}$ suspensions after $\mathrm{K}^{+}$transport had been inhibited. In these experiments (Table VII), $\mathrm{K}^{+}$influx values were calculated and then expressed as percentages of serum control values at 1 and $4 \mathrm{hr}$, respectively, after the addition of $2 \mathrm{ml}$ of control serum or of antidigoxin serum to $4 \mathrm{ml}$ of $\mathrm{RBC}$ suspensions which had been allowed to incubate with $1.5 \times 10^{-6} \mathrm{M}$ digoxin for 60 min before the addition of test sera. In the presence of control serum and of buffer alone there was a minimal increase in $\mathrm{K}^{+}$influx over a $4 \mathrm{hr}$ period. Only antidigoxin sera caused significant reversal of the effect of digoxin on $\mathrm{K}^{+}$influx, but the recovery of $\mathrm{K}^{+}$influx was a gradual one and was not complete at the end

TABLE V

Capacity of Test Sera to Remove Digoxin from Human Erythrocytes (RBC)

\begin{tabular}{|c|c|c|}
\hline Animal No. & Nature of serum & RBC Dig- ${ }^{3} \mathrm{H}$ \\
\hline & & $\begin{array}{c}\text { umoles / } \\
\text { liter } R B C^{*}\end{array}$ \\
\hline \multicolumn{3}{|l|}{ Control buffer and sera } \\
\hline None & Buffer control & 5.94 \\
\hline Sheep S-61 & Preimmunization & 7.20 \\
\hline Sheep S-62 & Preimmunization & 7.67 \\
\hline Sheep S-63 & Preimmunization & 5.82 \\
\hline Rabbit DB-87, 88, 89 Pool & Preimmunization & 4.90 \\
\hline Rabbit OVA-1 & Anti-ovalbumin & 4.95 \\
\hline Rabbit HSA-2 & Anti-HSA & 4.47 \\
\hline Rabbit HGG-2 & Anti-HGG & 4.62 \\
\hline \multicolumn{3}{|l|}{ Antidigoxin sera } \\
\hline Sheep S-61 & Anti-BSA-Dig & 0 \\
\hline Sheep S-62 & Anti-BSA-Dig & 0 \\
\hline Sheep S-63 & Anti-BSA-Dig & 0 \\
\hline Rabbit DB-20 & Anti-HSA-Dig & 0 \\
\hline Rabbit DB-46 & Anti-HSA-Dig & 0 \\
\hline Rabbit DB-87, 89 Pool & Anti-BSA-Dig & 0 \\
\hline
\end{tabular}

* $\mathrm{RBC}$ digoxin- ${ }^{3} \mathrm{H}$ concentration after $1 \mathrm{hr}$ incubation with digoxin, followed by addition of $2 \mathrm{ml}$ test serum and an additional $1 \mathrm{hr}$ incubation period; average of two duplicate determinations. Final digoxin concentration was $10^{-5} \mathrm{M}$. The Dig- ${ }^{-3} \mathrm{H}$ used in this experiment (lot R907) was subsequently found to contain 10-20\% radiochemical impurities ${ }^{13}$ but these impurities had little, if any, effect on calculated RBC digoxin concentrations, when compared with other $\mathrm{RBC}$ experiments employing more highly purified digoxin (Fig. 3 and 4, and unpublished experiments). In addition, the complete removal of detectable radioactivity from $\mathrm{RBC}$ by antidigoxin serum suggests that the RBC had not taken up any significant quantity of radioactive contaminants structurally unrelated to digoxin. 
TABLE VI

Inhibition of Potassium Influx into Human Erythrocytes by $10^{-5} \mathrm{M}$ Digoxin in the Presence of Antidigoxin Sera and other Test Sera*

\begin{tabular}{|c|c|c|c|c|}
\hline \multirow[b]{2}{*}{ Animal No. } & \multirow[b]{2}{*}{ Nature of serum } & \multicolumn{3}{|c|}{$\mathrm{K}^{+}$influx } \\
\hline & & $\begin{array}{c}\text { No } \\
\text { digoxin }\end{array}$ & $\begin{array}{c}10^{-6} \mathrm{M} \\
\text { digoxin }\end{array}$ & $\begin{array}{c}\text { Serum } \\
\text { control } \\
\text { value in } \\
\text { digoxin- } \\
\text { treated } \\
\text { RBC }\end{array}$ \\
\hline & & mmole/liter & $R B C$ per hr $¥$ & $\%$ \\
\hline \multicolumn{5}{|l|}{ Control buffer and sera } \\
\hline None & Buffer control & 1.87 & 0.39 & 21 \\
\hline Sheep S-61 & Preimmunization & 2.04 & 0.53 & 26 \\
\hline Sheep S-62 & Preimmunization & 2.08 & 0.52 & 25 \\
\hline Sheep S-63 & Preimmunization & 1.96 & 0.45 & 23 \\
\hline Rabbit DB-87, 88, 89 Pool & Preimmunization & 1.56 & 0.49 & 32 \\
\hline Rabbit OVA-1 & Anti-ovalbumin & 2.17 & 0.46 & 21 \\
\hline Rabbit HSA-2 & Anti-HSA & 1.91 & 0.37 & 19 \\
\hline Rabbit HGG-2 & Anti-HGG & 2.09 & 0.46 & 22 \\
\hline \multicolumn{5}{|l|}{ Antidigoxin sera } \\
\hline Sheep S-61 & Anti-BSA-Dig & 1.92 & 1.94 & 101 \\
\hline Sheep S-62 & Anti-BSA-Dig & 2.09 & 2.18 & 104 \\
\hline Sheep S-63 & Anti-BSA-Dig & 1.94 & 1.91 & 98 \\
\hline Rabbit DB-20 & Anti-HSA-Dig & 2.21 & 2.52 & 114 \\
\hline Rabbit DB-46 & Anti-HSA-Dig & 1.44 & 1.64 & 114 \\
\hline Rabbit DB-87, 89 Pool & Anti-BSA-Dig & 1.98 & 1.85 & 93 \\
\hline
\end{tabular}

* In experiments shown in this table, test sera and digoxin were added to RBC suspensions simultaneously (see text for details).

$\ddagger$ Average of duplicate determinations.

of $4 \mathrm{hr}$. At this time, $\mathrm{K}^{+}$influx had been restored to $67-76 \%$ of buffer control values. This slow recovery of $\mathrm{K}^{+}$influx (Table VII) was in sharp contrast with the rapid removal of digoxin from $\mathrm{RBC}$ by the same antisera under identical experimental conditions (Fig. 4, Table V).

\section{DISCUSSION}

In an earlier report, evidence was presented that rabbits immunized with synthetic protein-digoxin conjugates form antibodies capable of specific binding of tritiated digoxin (15). The demonstration, in equilibrium dialysis experiments, that sera obtained from animals immunized with HSA-Dig conjugates are capable of binding digoxin ${ }^{8} \mathrm{H}$, is in accord with these earlier observations.

The finding (Fig. 1) that renal cortical slices accumulate digoxin against a concentration gradient is in accord with the finding of Doherty and Perkins (34) who demonstrated in vivo that tritiated digoxin is accumulated in various tissues with tissue-to-serum distribution ratios considerably in excess of one; in their studies, the kidney concentrated digoxin more than any other tissue. The mechanism by which rat renal cortical slices accumulate digoxin and the kinetics of digoxin uptake by these slices are being reported in detail elsewhere. ${ }^{24}$

This study provides evidence that antidigoxin sera are capable of removing digoxin from rat renal cortical slices after these tissue slices have accumulated digoxin against a concentration gradient (Fig. 2, Table I). The capacity to remove digoxin from slices appeared in the sera of these rabbits as a consequence of immunization with HSA-Dig, since preimmunization sera from these same individual rabbits lacked the capacity to remove digoxin (Table I). This ability was a property of the $\gamma$-globulin fraction of antidigoxin sera (Table II). It did not develop as a nonspecific result of immunization because it was not present in the sera of rabbits immunized with antigens unrelated to digoxin (Table III). Further evidence for the immunologic specificity of the capacity to remove digoxin was obtained in the demonstration that this capacity, like the

${ }^{24}$ Watson, J. F., D. Hare, G. H. Cramer, and H. M. Tanenhaus. Digoxin uptake by rat renal cortical slices. Manuscript in preparation.

Biologic Activity of Digoxin-Specific Antisera 
TABLE VII

Restoration of Potassium Influx into Digoxin-Treated Human'Erythrocytes after Addition of Antidigoxin Serum

\begin{tabular}{|c|c|c|c|c|c|c|c|}
\hline \multirow[b]{2}{*}{ Animal No. } & \multirow[b]{2}{*}{ Nature of serum } & \multicolumn{3}{|c|}{$\begin{array}{c}\mathrm{K}^{+} \text {influx } \\
1 \mathrm{hr} \text { after addition of } 2 \mathrm{ml} \text { serum }\end{array}$} & \multicolumn{3}{|c|}{$\begin{array}{c}\mathrm{K}^{+} \text {influx } \\
4 \mathrm{hr} \text { after addition of } 2 \mathrm{ml} \text { serum }\end{array}$} \\
\hline & & $\begin{array}{c}\text { No } \\
\text { digoxin* }\end{array}$ & $\begin{array}{c}10^{-6} \mathrm{M} \\
\text { digoxin* }\end{array}$ & $\begin{array}{l}\text { Serum } \\
\text { control } \\
\text { value in } \\
\text { digoxin- } \\
\text { treated } \\
\text { RBC }\end{array}$ & $\begin{array}{c}\text { No } \\
\text { digoxin* }\end{array}$ & $\begin{array}{l}10^{-5} \mathrm{M} \\
\text { digoxin* }\end{array}$ & $\begin{array}{c}\text { Serum } \\
\text { control } \\
\text { value in } \\
\text { digoxin- } \\
\text { treated } \\
\text { RBC }\end{array}$ \\
\hline \multirow{2}{*}{ Control buffer and sera } & & \multicolumn{2}{|c|}{ mmole/liter $R B C$ per $h r$} & $\%$ & \multicolumn{2}{|c|}{ mmole/liter $R B C$ per $h r$} & $\%$ \\
\hline & Buffer control & 1.31 & 0.33 & 25 & 1.04 & 0.31 & 30 \\
\hline Sheep S-61 & Preimmunization & 1.33 & 0.35 & 26 & 1.26 & 0.37 & 30 \\
\hline Sheep S-62 & Preimmunization & 1.22 & 0.33 & 27 & 0.81 & 0.30 & 36 \\
\hline Sheep S-63 & Preimmunization & 1.27 & 0.33 & 26 & 0.96 & 0.34 & 35 \\
\hline Rabbit DB-87, 88, 89 Pool & Preimmunization & 1.49 & 0.43 & 29 & 1.46 & 0.43 & 29 \\
\hline Rabbit OVA-1 & Anti-ovalbumin & 1.31 & 0.39 & 30 & 0.95 & 0.40 & 42 \\
\hline Rabbit HSA-2 & Anti-HSA & 1.24 & 0.33 & 27 & 1.11 & 0.36 & 32 \\
\hline Rabbit HGG-2 & Anti-HGG & 1.39 & 0.39 & 28 & 1.31 & 0.37 & 32 \\
\hline \multicolumn{8}{|l|}{ Antidigoxin sera } \\
\hline Sheep S-61 & Anti-BSA-Dig & 1.58 & 0.59 & 37 & 1.34 & 0.91 & 68 \\
\hline Sheep S-62 & Anti-BSA-Dig & 1.04 & 0.47 & 45 & 1.06 & 0.81 & 76 \\
\hline Sheep S-63 & Anti-BSA-Dig & 1.59 & 0.70 & 44 & 1.58 & 1.05 & 67 \\
\hline Rabbit DB-20 & Anti-HSA-Dig & 1.45 & 0.47 & 33 & 1.30 & 0.90 & 69 \\
\hline Rabbit DB-46 & Anti-HSA-Dig & 1.23 & 0.51 & 41 & 1.20 & 0.80 & 67 \\
\hline
\end{tabular}

* Cells were preincubated for $60 \mathrm{~min}$ in buffer or $1.5 \times 10^{-5} \mathrm{M}$ digoxin in $4 \mathrm{ml}$ reaction volume. $2 \mathrm{ml}$ of test serum was added at $0 \mathrm{hr}$ to make final digoxin concentration of $10^{-5} \mathrm{M}$. All determinations were performed in duplicate.

capacity to bind digoxin in equilibrium dialysis, is significantly diminished by prior absorption with an HSADig conjugate whereas prior absorption with the HSA carrier protein alone was without effect (Table IV).

This study also provides evidence that antidigoxin sera, but not control sera, are capable of removing digoxin from human $\mathrm{RBC}$ after these erythrocytes have taken up the glycoside (Fig. 4, Table V). This removal is rapid and, within limits of experimental error, appears to be complete in cells examined $10 \mathrm{~min}$ after the addition of antiserum (Fig. 4).

Digoxin-specific antibodies are known to have high affinity for digoxin (17), but the precise mechanisms by which these antibodies remove the glycoside from rat kidney cells and from human erythrocytes has not been determined in the present study. Presumably, when extracellular digoxin is bound by antibody, the effective extracellular concentration of "free"glycoside is decreased, thereby creating a new concentration gradient which would theoretically promote the reentry into the extracellular space of cellular (intracellular and/or cell membrane-bound) digoxin. Although it seems likely that such a process occurs, direct evidence for this mechanism is lacking. It is also possible that antibody binds cell membrane-bound digoxin (35) directly, thereby removing it from cellular sites of attachment. It is known that antibodies may, under certain circumstances, enter nonendocytotic mammalian cells (36). However, if digoxin-specific antibody entered renal and erythrocytic cells in significant amounts, one would anticipate the detection of significant quantities of cellular digoxin due to the presence of antibody-digoxin complexes in the intracellular fluid; thus the absence of significant amounts of cellular digoxin after exposure to antibody makes this latter mechanism of removal seem unlikely.

Normal sheep or rabbit serum and rabbit antiserum to antigens unrelated to digoxin exerted no significant effect on the capacity of digoxin to inhibit the influx of potassium into human erythrocytes. However, digoxin was not capable of exerting its effect on the influx of potassium into these cells when the glycoside was added to red cells in the presence of antidigoxin serum ( $\mathrm{Ta}-$ ble VI). These experiments provided evidence that digoxin-specific antibodies could prevent digoxin from exerting certain of its pharmacological effects, but they did not provide any information concerning whether reversal of a pharmacological effect might occur after digoxin had been removed from cells upon which 
digoxin had already exerted such an effect. Accordingly, antidigoxin serum was added to red cells in which $\mathrm{K}^{+}$ influx had been inhibited during $60 \mathrm{~min}$ of exposure to $10^{-b} \mathrm{M}$ digoxin. Antidigoxin serum was found to be capable of reversal of much of the inhibitory effect of digoxin on $\mathrm{K}^{+}$influx (Table VII), thus demonstrating that, in removing digoxin from erythrocytes, digoxinspecific antibody was capable of reversing a pharmacologic effect of the glycoside on cation transport.

However, despite the rapid and essentially quantitative removal of digoxin by antiserum (Fig. 4, Table $\mathrm{V})$, restoration of potassium influx toward normal control values was delayed. $60 \mathrm{~min}$ after addition of antidigoxin antibody, restoration of potassium transport was slight and, in representative experiments (Table VII), a lag of $4 \mathrm{hr}$ occurred before $\mathrm{K}^{+}$influx was restored to $67-76 \%$ of serum control values. It would therefore appear that a delay occurs between removal of $\mathrm{RBC}$ digoxin and reversal of the pharmacologic effect of the glycoside on cation transport.

The basis for the delay between removal of digoxin from erythrocytes and subsequent restoration of potassium transport is not known, but a knowledge of the mechanism for this delay might provide useful information concerning the mechanism of action of digoxin on individual cells. Three possible mechanisms have been considered: $(a)$ the cardiac glycoside-sensitive, Na-K-dependent "transport" ATPase of mammalian cell membranes is known to bind digoxin (35) with a resultant decrease in potassium influx (33). It is possible that a small fraction of the $\mathrm{Dig}-{ }^{3} \mathrm{H}$, not detectable by the methods used in the current study, is bound with high affinity to, and released more slowly from, such a specific cellular cation transport system than is the majority of cellular digoxin which is promptly removed by antibody. ( $b$ ) the delay between quantitative digoxin removal and restoration of $\mathrm{K}^{+}$influx is consistent with the hypothesis that the cation transport system is depleted of an unknown substance, or substances, during exposure to digoxin and that this substance is restored or resynthesized at a relatively slow rate after removal of digoxin from cells. (c) a related hypothesis is that an unknown inhibitory substance, or substances, is accumulated by the cation transport system during incubation with digoxin and that this substance is removed or inactivated at a slow rate after the removal of cellular digoxin.

These experiments provide direct evidence that antibodies to low molecular weight substances are capable of removing, and thereby reversing the biological effect of, physiologically active low molecular weight substances after these substances have entered mammalian cells. Thus, these studies suggest that antibodies specific for physiologically active low molecular weight substances may be useful in the study of the mechanism of action of these compounds. Moreover, such antibodies may be useful in the reversal of toxic cellular effects of certain low molecular weight compounds. For example, these studies indicate that antidigoxin antibodies are capable of removing the glycoside from tissues incubated in a medium containing $10^{-5} \mathrm{M}$ digoxin. Since serum concentrations in human subjects with clinical evidence of toxicity are usually in the $10^{-8}-10^{-9} \mathrm{M}$ range $(37,38)$, these findings have suggested that digoxin-specific antibodies may eventually be of value in the clinical management of patients who have received excessive amounts of this glycoside. In this connection, evidence has recently been obtained that antidigoxin antibodies are capable of reversing digoxin toxicity in the dog (39).

\section{ACKNOWLEDGMENTS}

Superb technical assistance was provided by Rose Beckhorn, Amy Johnson, Beth Ross, Ann Wargo, Marsha Powell, Toni Greene, and Diane Lepore.

This work was supported by U. S. Public Health Service research grants AM-10418, HE-10608, HE-05741, and AM07183, and by grants from the American Heart Association (67-681 and 69-824), the New York Heart Association, the New York Chapter of the Arthritis Foundation, and the Lupus Erythematosus Foundation.

\section{REFERENCES}

1. Watson, J. F., and V. P. Butler. 1967. Biologic activity of digoxin-specific antisera. Clin. Res. 15: 483. (Ábstr.).

2. Watson, J. F., and V. P. Butler. 1968. Biologic activity of digoxin-specific antisera. Clin. Res. 16: 252. (Abstr.).

3. Cinader, B., and I. H. Lepow. 1967. The neutralization of biologically active molecules. Proc. 2nd Meet. Fed. Eur. Biochem. Soc. 1: 1.

4. Pastan, I., J. Roth, and V. Macchia. 1966. Binding of hormone to tissue: the first step in polypeptide hormone action. Proc. Nat. Acad. Sci. U. S. A. 56: 1802.

5. Landsteiner, K. 1962. The Specificity of Serological Reactions. Dover Publications, Inc., New York.

6. Beiser, S. M., V. P. Butler, and B. F. Erlanger. 1968. Hapten-protein conjugates: methodology and application. In Textbook of Immunopathology. P. A. Miescher and $H$. J. Muller-Eberhard, editors. Grune \& Stratton, Inc., New York. 15.

7. Lieberman, S., B. F. Erlanger, S. M. Beiser, and F. J. Agate. 1959. Steroid-protein conjugates: their chemical, immunochemical and endocrinological properties. Recent Progr. Hormone Res. 15: 165.

8. Goodfriend, L., and A. H. Sehon. 1961. Antibodies to estrone-protein conjugates. II. Endocrinological studies. Can. J. Biochem. Physiol. 39 : 961.

9. Neri, R. O., S. Tolksdorf, S. M. Beiser, B. F. Erlanger, F. J. Agate, and S. Lieberman. 1964. Further studies on the biological effects of passive immunization with antibodies to steroid-protein conjugates. Endocrinology. 74 : 593.

10. Ranadive, N. S., and A. H. Sehon. 1967. Antibodies to serotonin. Can. J. Biochem. 45 : 1701.

Biologic Activity of Digoxin-Specific Antisera 
11. Ungar-Waron, H., and M. Sela. 1966. Pyridoxal-specific antibodies obtained with a synthetic pyridoxalpolypeptide conjugate. Biochim. Biophys. Acta. 124: 147.

12. Davis, T. R. A., and K. M. Meade. 1970. Biologically active antibodies to histamine. Nature (London). 226: 360.

13. Oken, D. E., and T. U. L. Biber. 1968. Biologically effective immunization against angiotensin. Amer. $J$. Physiol. 214 : 791.

14. Davis, T. R. A., and T. L. Goodfriend. 1969. Neutralization of airway effects of bradykinin by antibodies. Amer. J. Physiol. 217 : 73.

15. Butler, V. P., and J. P. Chen. 1967. Digoxin-specific antibodies. Proc. Nat. Acad. Sci. U. S. A. 57: 71.

16. Erlanger, B. F., and S. M. Beiser. 1964. Antibodies specific for ribonucleosides and ribonucleotides and their reaction with DNA. Proc. Nat. Acad. Sci. U. S. A. 52: 68.

17. Smith, T. W., V. P. Butler, and E. Haber. 1970. Characterization of antibodies of high affinity and specificity for the digitalis glycoside digoxin. Biochemistry. 9: 331

18. Butler, V. P., S. M. Beiser, B. F. Erlanger, S. W. Tanenbaum, S. Cohen, and A. Bendich. 1962. Purinespecific antibodies which react with deoxyribonucleic acid (DNA). Proc. Nat. Acad. Sci. U. S. A. 48: 1597.

19. Kabat, E. A. 1961. Kabat and Mayer's Experimental Immunochemistry. Charles C. Thomas, Publisher. Springfield, Ill. 2nd edition.

20. Tomasi, T., and H. G. Kunkel. 1964. Isolation of 7S and 19S gamma globulins. Methods Med. Res. 10: 80.

21. Butler, V. P., S. W. Tanenbaum, and S. M. Beiser. 1965. A study of the cross-reactivity of antipurin-6-oyl serum with deoxyribonucleic acid (DNA). J. Exp. Med. $121: 19$.

22. Waldi, D. 1965. Steroids. Sterols; pregnane-, androstane-, and estrane-compounds; bile acids and cardiac glycosides. In Thin Layer Chromatography. E. Stahl, editor. Academic Press, Inc. New York. 249.

23. Bray, G. A. 1960. A simple efficient liquid scintillator for counting aqueous solutions in a liquid scintillation counter. Anal. Biochem. 1 : 279.

24. Eisen, H. N. 1964. Equilibrium dialysis for measurement of antibody-hapten affinities. Methods Med. Res. $10: 106$.

25. Rosenberg, L. E., S. J. Downing, and S. Segal. 1962. Extracellular space estimation in rat kidney slices using
$\mathrm{C}^{14}$ saccharides and phlorizin. Amer. J. Physiol. 202: 800.

26. Rosenberg, L. E., A. Blair, and S. Segal. 1961. Transport of amino acids by slices of rat-kidney cortex. Biochim. Biophys. Acta. 54 : 479.

27. Doherty, J. E., W. H. Perkins, and G. K. Mitchell 1961. Tritiated digoxin studies in human subjects. Arch. Intern. Med. 108: 531.

28. Kaiser, F. 1955. Die papierchromatographische Trennung von Herzgiftglykosiden. Chem. Ber. 88: 556.

29. Patterson, M. S., and R. C. Greene. 1965. Measurement of low energy beta-emitters in aqueous solution by liquid scintillation counting of emulsions. Anal. Chem. $37: 854$

30. Sachs, J. R., and L. G. Welt. 1967. The concentration dependence of active potassium transport in the human red blood cell. J. Clin. Invest. 46: 65.

31. Crosby, W. H., J. L. Munn, and F. W. Furth. 1954. Standardizing a method for clinical hemoglobinometry. U. S. Armed Forces Med. J. 5: 693.

32. Macknight, A. D. C. 1968. The extracellular space in rat renal cortical slices incubated at $0.5^{\circ}$ and $25^{\circ}$. Biochim. Biophys. Acta. 163: 85.

33. Glynn, I. M. 1964. The action of cardiac glycosides on ion movements. Pharmacol. Rev. 16: 381

34. Doherty, J. E., and W. H. Perkins. 1966. Tissue concentration and turnover of tritiated digoxin in dogs. Amer. J. Cardiol. 17: 47

35. Matsui, H., and A. Schwartz. 1968. Mechanism of cardiac glycoside inhibition of the $\left(\mathrm{Na}^{+}-\mathrm{K}^{+}\right)$-dependent ATPase from cardiac tissue. Biochim. Biophys. Acta. $151: 655$.

36. Ng, C. W., and K. F. Gregory. 1968. Antibody to lactate dehydrogenase. III. Uptake, accumulation, and specific intracellular action in malignant cells. Biochim. Biophys. Acta. 170: 45.

37. Smith, T. W., V. P. Butler, and E. Haber. 1969. Determination of therapeutic and toxic serum digoxin concentrations by radioimmunoassay. $N$. Engl. J. Med. 281: 1212.

38. Smith, T. W., and E. Haber. 1970. Digoxin intoxication: the relationship of clinical presentation to serum digoxin concentration. J. Clin. Invest. 49: 2377.

39. Schmidt, D. H., and V. P. Butler, 1971. Reversal of digoxin toxicity with specific antibodies. J. Clin. Invest. 50: 1738 . 